\title{
Enhanced at Puberty-1 (Eap1) Expression Critically Regulates the Onset of Puberty Independent of Hypothalamic Kiss1 Expression
}

\author{
Chenxi Li Pin Li \\ Department of Endocrinology, Shanghai Children's Hospital, Shanghai Jiao Tong University, Shanghai, \\ China
}

\author{
Key Words \\ Eap1 • KiSS1 • Lentiviral-mediated RNAi • Puberty
}

\begin{abstract}
Background/Aims: Enhance at puberty-1 (Eap1) is an intronless gene that regulates the onset of puberty through a network of hypothalamic genes. However, precise mechanistic events essential for Eap1-regulation of puberty have not been fully elucidated. Eap1 is thought to promote the initiation of puberty through regulation of the hypothalamic metastasissuppressor KiSS1. We aim to investigate this hypothesis by genetically perturbing Eap1 through RNA interference in vivo. Methods: We first engineered and optimized four sets of shRNAs that target rat Eap1 mRNA as well as one negative control shRNA. After generating lentiviral (LV) particles, we examined the suppression of Eap1 in NRK-54E cell line to select the most efficient one. Sequencelly, LV-Eap1-shRNA or controls including LV-eGFP and saline were intraventricular microinjected into 21-day-old rats. Rats were raised in appropriate conditions and we examined the time of vaginal opening, ovary physiology as well as hypothalamic puberty-regulatory genes at three developmental stages: juvenile (postnatal day PND25), early puberty (PND35), adult (PND42). Results: Hypothalamic suppression of Eap1 delayed the onset of rat vaginal opening. Hematoxylin and eosin (H\&E) staining revealed a significant reduction of corpus luteum $(\mathrm{CL})$ at PND35, but at PND42 CL levels were normal relative to control. In conjunction with differences in phenotype and ovary morphology, GnRH expression and transcripts were also reduced at PND25 and PND35, while their levels were similar to control at PND42. KiSS1 mRNA and protein levels were not significantly different at all three developmental stages. Conclusion: Eap1 expression critically regulates puberty as well as GnRH expression. However, Eap1-regulation of puberty may not necessitate KiSSI/ GPR54 signaling.
\end{abstract}




\section{Introduction}

The onset of puberty is regulated by the hypothalamic-pituitary-gonadal (HPG) axis, which is inactive during childhood. Activation of gonadotropin-releasing hormone (GnRH)expressing neurons in the hypothalamus triggers the onset of puberty [1]. However, the exact molecular mechanism underlying sexual maturation in the brain remains poorly understood. In the past decades, several comprehensive studies have together revealed that hypothalamic control of puberty is not determined by a single gene. Instead, a sophisticated gene network in the hypothalamus controls this event hierarchically [2, 3]. In 2007, Heger et al. [4]. first identified patterns of increased C4ORF4 mRNA in the hypothalamus of nonhuman primates during puberty. Furthermore, they found that C4ORF4 played an important role in regulating the onset of puberty as well as maintenance of reproductive function. They subsequently renamed it enhanced at puberty-1 (Eap1) and numerous studies have since exmined this gene. However despite such efforts, the precise molecular mechanism of Eap1regulation of puberty remains unclear. Matagneet et al. [5]. reported that Eap1 must be centrally regulated as they detect enhanced expression during puberty occurs even in the absence of ovaries. Ojeda et al. [6]. reported that Eap1 plays a dual role in transcriptional activities (it trans-activates secretion promoting genes while suppresses inhibitory genes of GnRH neuronal function). More recently, a mechanistic study demonstrated that Eap1 is recruited to the KiSS1 promoter, and paired immunofluorescence assays showed Eap1 and kisspeptin are co-expressed in neurons in the medial basal hypothalamus [7]. This suggests that Eap1 may transcriptionally regulate KiSS1 gene expression. Several studies demonstrate that Kisspeptin robustly stimulates the secretion of GnRH through the KiSS1/GPR54 signal pathway and plays a pivotal role in the initiation of puberty. Furthermore, KiSS1 neurons integrate several factors that influence Gnrh-neurons activation, these include nutritional status, environmental cues, and socioeconomic factors [8].

In agressment with other studied, we previously demonstrated that the number of Eap1 immuno-positive cells in the hypothalamus peaked in early puberty but declined in adulthood [9]. Moreover, the Eap1-expressing neurons were proximally distributed around kiSS1 and GnRH expressing neurons. These data suggest that Eap1 may regulate the HPGaxis through stimulation of the kisspeptin/GPR54 signaling pathway. To test this hypothesis, we utilized RNAi to experimentally examine the consequences of rat hypothalamic Eap1 suppression in conjunction with observing key events associated with the onset of puberty, paralleled by specific detection of key regulators KiSS1 and GnRH.

\section{Materials and Methods}

\section{Animals}

Sprague-Dawley rats at 21 days of age were purchased from Shanghai SLAC Laboratory Animal Co. (Shanghai, China) and randomly divided into three groups: saline, lentivirus (LV)-enhanced green fluorescent protein (eGFP), and LV-Eap1-shRNA. Upon arrival, they were subjected to intracerebroventricular microinjections between hours 13:00 and 17:00. The rats were then housed under controlled temperature $\left(21 \pm 2^{\circ} \mathrm{C}\right)$ and humidity $(55 \pm 10 \%)$ conditions, with a $12 \mathrm{~h}$ light/12h dark cycle (lights on at hours 7:00 -19: 00). Food and water were provided ad libitum. The animals were inspected for vaginal opening every afternoon between hours 16:00 and 17:00. Finally, the rats were euthanized at the juvenile, early puberty, and adult stages (PND25, PND35, and PND42, respectively) between hours 16:00 and 17:00. All experiments were approved by the Institutional Animal Care and Use Committee of Shanghai, China.

\section{Cell culture}

NRK-52E, a kidney epithelial cell line (Cell Bank of the Chinese Academy of Sciences) which can express the EAP1 gene, was cultured in a humidified atmosphere containing $5 \% \mathrm{CO}_{2}$ and $37^{\circ} \mathrm{C}$. The cells were maintained in Dulbecco's modified Eagle's medium (DMEM) containing 5\% fetal bovine serum (FBS, Gibco), $1.5 \mathrm{mM}$ glutamine, $100 \mathrm{U} / \mathrm{mL}$ penicillin, and $100 \mu \mathrm{g} / \mathrm{mL}$ streptomycin. 


\section{Cellular Physiology Cell Physiol Biochem 2017;43:1402-1412 \begin{tabular}{l|l|l} 
and Biochemistry & Published onlIne: October 11, 2017 & $\begin{array}{l}\text { C } 2017 \text { The Author(s). Published by S. Karger AG, Basel } \\
\text { www.karger.com/cpb }\end{array}$
\end{tabular}}

Li/Li: EAP1 Effect on Kiss1 in Vivo

293T cells (Cell Bank of the Chinese Academy of Sciences) were cultured in DMEM containing $10 \%$ FBS, 4.0 $\mathrm{mM}$ glutamine, $100 \mathrm{U} / \mathrm{mL}$ penicillin, and $100 \mu \mathrm{g} / \mathrm{mL}$ streptomycin, and were cultured in a humidified atmosphere containing $5 \% \mathrm{CO}_{2}$ at $37^{\circ} \mathrm{C}$.

Construction of lentiviral-Eap1-shRNA and efficacy test of LV-Eap1-shRNA

The Designer3.0 (Gene-Pharma) software was used to design four pairs of oligonucleotide sequences targeting the Eap1 gene as well as a negative sequence, as shown in Table 1. Each Eap1-shRNA sequence contained a 21-nt sense strand, a TTCAAGAGA-loop, and a 21-nt antisense strand. For the purpose of cloning, BamHI (GATCC) and EcoRI (AATTC) sequences were respectibely added to the 5 ' and 3' flanking regions. These oligonucleotide sequences were cloned into the LV3 vector (Gene-Pharma) through restriction enzyme-mediated digestion and ligation with T4 DNA ligase. The resulting constructs were then transfected into 293T cells after precipitation in calcium phosphate method [10]. This procedure was utilized to identify the Eap1 shRNA that led to optimal suppression.

Lentiviral (LV) particle production.

To engineer lentiviral (LV) particles, we adapted the RNAi-Mate (Gene-Pharma) protocol to co-transfect 293T cells with three packaging plasmids (pGag/Pol, pRev, and pVSV-G) with the described LV-shRNA vector. After $72 \mathrm{~h}$, the LV particles were collected, and the viral titer was determined after infecting separate 293T cells with serial dilutions of the viral stock, subsequent selection and determination of multiplicity of infection. The resulting virus was subsequently stored at $-80^{\circ} \mathrm{C}$.

NRK-52E cells were seeded in a six-well plate at a density of $4 \times 10^{4}$ cells/well in antibiotic-free DMEM for $24 \mathrm{~h}$. In parallel, they were next infected with tittered LV mixtures containing 1 of 4 shRNA against Eap 1 (LV-Eap1-shRNA1-4) or control (LV-eGFP) as well as polybrene $(5 \mu \mathrm{g} / \mathrm{mL})$. Total RNA and protein were separately extracted 72 and $96 \mathrm{~h}$ post infection to deternime the magnitude of Eap1suppression.

Intracerebroventricular injections of LV particles

For intracerebronventricular injections, we adapted procedures from our previous study [11]. Briefly, 21-day-old rats were positioned in a stereotaxic instrument after they were deeply anesthetized with $1 \%$ sodium pentobarbital $(0.5 \mathrm{~mL} / 100 \mathrm{~g}$ body weight).The skin and periosteum were incised to expose the bregma point, and a microsyringe with $40 \mu \mathrm{LV}-(-)$, LV-Eap1-shRNA1-4, or saline was inserted into the skull at a $90^{\circ}$ angle (parameters: $0.8 \mathrm{~mm}$ rostral from bregma, $1.5 \mathrm{~mm}$ lateral from midline, and $3.5 \mathrm{~mm}$ ventral from the surface of the skull). This was held for 5-10 min and then slowly injected at a speed of $4 \mu \mathrm{l} / \mathrm{min}$, and the syringe was retained for another 5-10 min before it was removed.

\section{Tissue preparation}

Rats were anesthetized with $1 \%$ sodium pentobarbital $(0.5 \mathrm{~mL} / 100 \mathrm{~g}$ body weight), decapitated to collect the whole brain and subsequently frozen on dry ice. Brains were serially sectioned using a cryostat. Two hypothalamic regions (preoptic area/anteroventral periventricular nucleus (POA/AVPV) and (arcuate nucleus ARC)) were microdissected according to the anatomical landmarks by a stereotaxic coordinate atlas. The POA/AVPV (POA which contains GnRH neurons while AVPV consists of one of the two populations of KiSS1-expressing neurons) was cut into 100 - $\mu \mathrm{m}$ section and dissected from six consecutive sections. The ARC (the other population of KiSS1-expressing neurons) was cut into 300- $\mu$ m section and dissected from eight consecutive sections. The tissues were also used to assay for RNA or protein expression. Finally, the ovaries were also collected and weighed from the euthanized rats.

Hematoxylin and eosin (H\&E) staining and quantification of corpous luteum (CL)

Ovaries were fixed in $4 \%$ paraformaldehyde at $4{ }^{\circ} \mathrm{C}$ for $8 \mathrm{~h}$. Subsequently they were dehydrated in a series of ethanol concentrations, cleared in xylene, embedded in paraffin, and serially sectioned at $6 \mu \mathrm{m}$. Six representative sections were selected from each ovary; these were deparaffinized in xylene, hydrated 


\section{Cellular Physiology Cell Physiol Biochem 2017;43:1402-1412 and Biochemistry Published \begin{tabular}{l|l} 
DOI: 10.1159/000481872 & $\begin{array}{l}\text { C } 2017 \text { The Author(s). Published by S. Karger AG, Basel } \\
\text { www.karger.com/cpb }\end{array}$ \\
\hline
\end{tabular}}

Li/Li: EAP1 Effect on Kiss1 in Vivo

through a series of ethanol concentrations, and stained with H\&E. Only the nascent CL defined as formed after ovulation, was counted. Nascent CL was distinguished from the large existing follicles through examination of angiogenesis between the granulosa cell

Table 2. Primers used for q-PCR

\begin{tabular}{lccc}
\hline Gene & Forward primer $\left(5^{\prime}-3^{\prime}\right)$ & Reverse primer $\left(5^{\prime}-3^{\prime}\right)$ & Product length (bp) \\
\hline KiSS1 & AGCTGCTGCTTCTCCTCTGT & AGGCTTGCTCTCTGCATACC & 152 \\
GnRH & CCGCTGTTGTTCTGTTGACTGTG & GGGGTTCTGCCATTTGATCCTC & 150 \\
Eap1 & CTTGCTACCTGTGCG AC & GTGCTGTCTCGATCA CG & 126 \\
$\beta$-Actin & TGCCGCATCCTCTTCCT & GGTCTTTACGGATGTCAACG & 191 \\
\hline
\end{tabular}
layer and the theca layer. Although existing and nascent CL aresimilar in size, degenerative processes such as fibrosis are more advanced in existing CL and was used as an additional marker for distinction.

\section{Reverse transcription and quantitative polymerase chain reaction (qPCR)}

Total RNA was extracted using the TRIzol reagent (Invitrogen, USA) according to the manufacturer's instructions. After the RNA was concentrated and purified $1 \mu \mathrm{g}$ of each sample was reverse-transcribed into cDNA, and qPCR was performed in a final mixture of $20 \mu \mathrm{L}$. The PCR conditions were as follows: initial denaturation at $95^{\circ} \mathrm{C}$ for $1 \mathrm{~min} .40$ cycles of denaturation at $95^{\circ} \mathrm{C}$ for $10 \mathrm{~s}$, annealing at $60^{\circ} \mathrm{C}$ for $30 \mathrm{~s}$, and extension at $72^{\circ} \mathrm{C}$ for $1 \mathrm{~min}$. And a final extension step was included at $72^{\circ} \mathrm{C}$ for $7 \mathrm{~min}$. Each qPCR reaction was performed in triplicate. The primers (Table 2) were synthesized by Shanghai Sangon Biotech Co., Ltd., and $\beta$-actin primers were used as the internal control.

\section{Western blotting}

Cell or hypothalamus tissue samples were homogenized in lysis buffer (Thermo Fisher, USA) containing a protease inhibitor cocktail. The supernatant was collected after centrifugation at $14,000 \mathrm{rpm}$ for $15 \mathrm{~min}$ at $4^{\circ} \mathrm{C}$, and the protein concentration was determined using the bicin choninic acid (BCA) assay kit. Protein samples were separated using $10 \%$ or $15 \%$ sodium dodecyl sulfate-polyacrylamide gel electrophoresis (SDS-PAGE ) (for Eap1 and kisspeptin, respectively), and then transferred onto nitrocellulose (NC) membranes. The membranes were blocked with $5 \%$ nonfat milk for $1 \mathrm{~h}$ at $4^{\circ} \mathrm{C}$, incubated with anti-Eap1 (1:500, Sigma-Aldrich), or anti-kisspeptin(1:500, Cell Signaling Technologies) antibodies at $4^{\circ} \mathrm{C}$ overnight, or anti-glyceraldehyde 3-phosphate dehydrogenase (GAPDH) antibody (1:1000, Cell Signaling Technologies) at $4^{\circ} \mathrm{C}$ for $2 \mathrm{~h}$. Subsequently, the membranes were rinsed three times with Tris-buffered saline with Tween (TBST) every 5-10 min, and probed with secondary antibody (1:10000, HRP labeled, Jackson, U.S.A.) at $24^{\circ} \mathrm{C}$ for $1 \mathrm{~h}$. After three additional rinses with TBS, the membranes were developed using an enhanced chemiluminescence (ECL) reagent.

\section{Statistical analysis}

The Statistical Package for the Social Sciences (SPSS) version 13.0 statistical software was used for the analysis. The data were expressed as mean \pm standard deviation (SD) and the significance of the differences between groups was analyzed using one-way analysis of variance (ANOVA). The level of significance was $p$ $<0.05$.

\section{Results}

\section{Engineering and optimization of Eap1 suppression in cells}

We fist sought to engineer a model that permits clear detection of Eap1 suppression in tissue. LV3 backbones containing eGFP driven by a separate CMV promoter were used to engineer shRNA constructs as indicated in Fig. 1A, and the sequencing results authenticated each cloned contruct (Fig. 1B, LV-shRNA4 is shown as an example). We also optimized lentivirus (LV) titer. Specifically, the viral stock solution was serially diluted to obtain four concentrations 10-fold apart, and these were subsequently used to infect $293 \mathrm{~T}$ cells. Based on the population of GFP-fluorescent cells, the titer of the LV-shRNA was calculated at 3.8 $\times 10^{8} \mathrm{TU} / \mathrm{mL}$ (Fig. $1 \mathrm{C}$ ). 
A

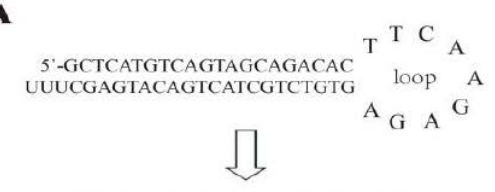

GCTCATGTCAGTAGCAGACACUu uUUCGAGTACAGTCATCGTCTGTG
B

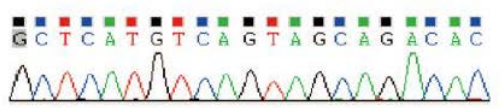

C

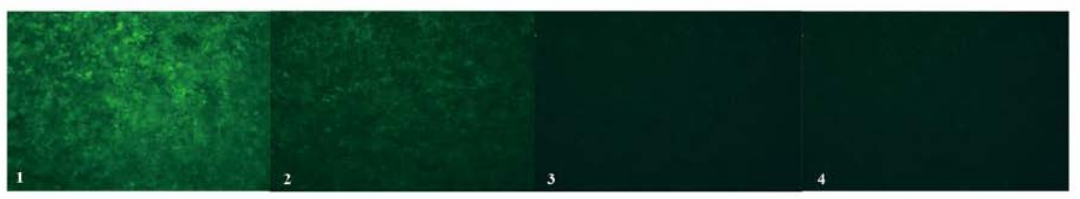

Fig. 1. A. Construction of shRNA. B. Validation of shRNA sequences. shRNA4 is shown as an example. C. To determine the titer of LV particles, four serial diluents of the virus stock solution were used to infect 293T cells.

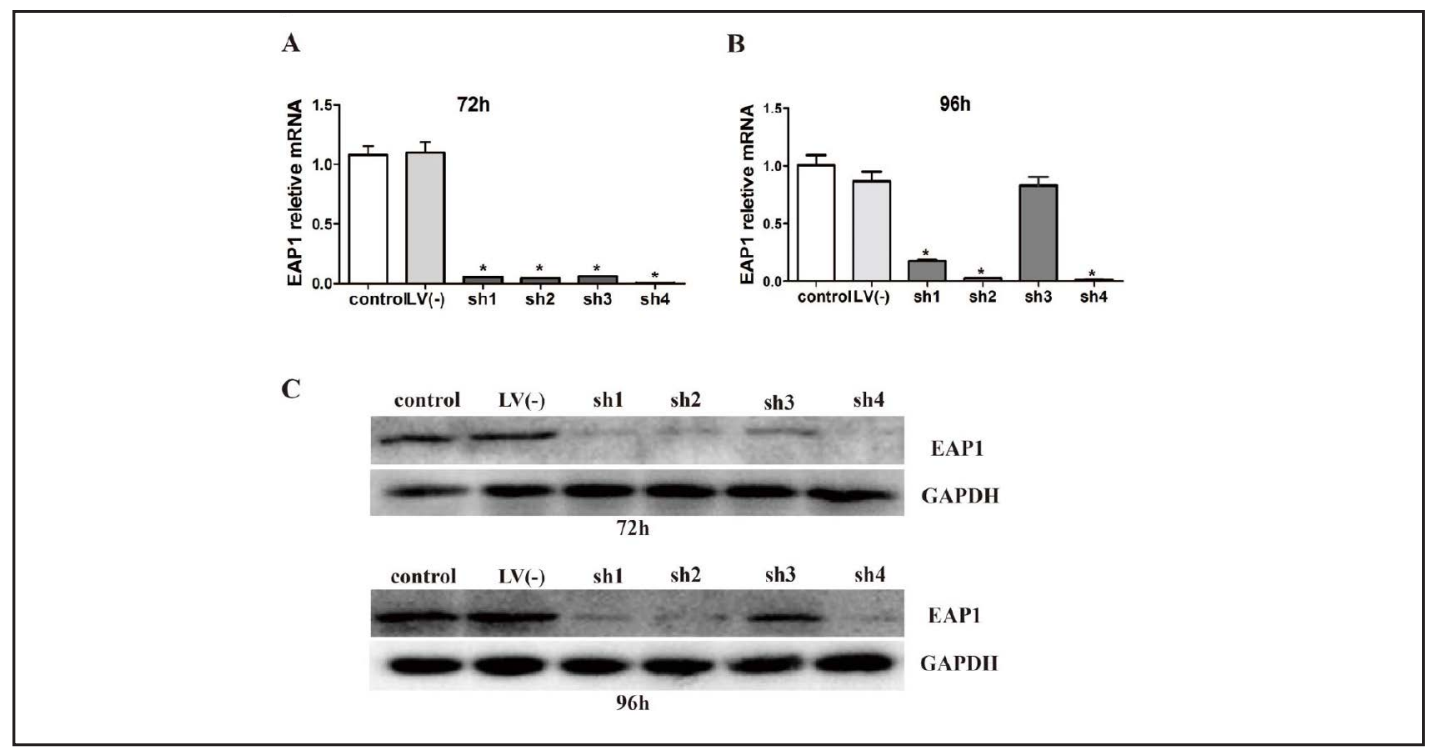

Fig. 2. Determination of Eap1 suppression efficacy for respective LV-EAP1-shRNAs in Nk-52E cells. A, B. mRNA levels were analyzed after transfection with different shRNAs relative to controls LV-eGFP or saline. We observed reduction of Eap1 expression after 72 and 96 hours post transfection of the respective shRNAs. C. Eap1 protein concentrations were determined by western blots.

To determine the relative efficacy of Eap1 suppression, NRK-52E cells were in parallel transfected with LV-Eap1-shRNAs or LV-eGFP. Eap1 mRNA and protein levels were measured 72 and 96 hours post transfection. As shown in Fig. 2A and B, infection with LV-Eap1-shRNAs reduced EAP1 transcripts, and relative to LV-eGFP, shRNA1-4 suppressed expression at 99.4, 95.7, 93.8, and $99.7 \%$ at $72 \mathrm{~h}$ while at $82.5,97.5,17.6$, and $98.7 \%$ at $96 \mathrm{~h}$, (Fig. $2 \mathrm{~A}$ and B). We further confirm relative suppression of Eap1 protein expression through western blots (Fig. 2C and D). In summary, we engineered a GFP co-expressing lentiviral construct (LV-shRNA4) that effectively suppresses Eap1 for the use in subsequent experiments.

In vivo suppression of Eap1 in rat bypothalamus via intracerebroventricular injection

After intracerebroventricular injection of the respective LV, we next confirmed LV particles penetrated the lateral ventricle to the third ventricle and infected proximal cells. 
$\mathbf{A}$

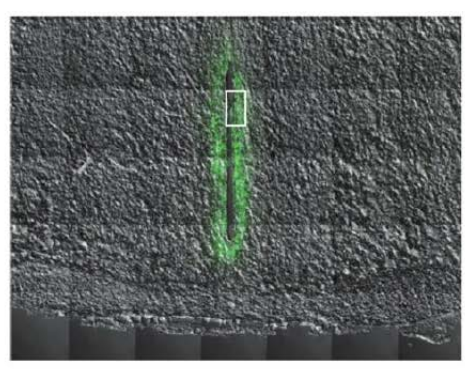

B

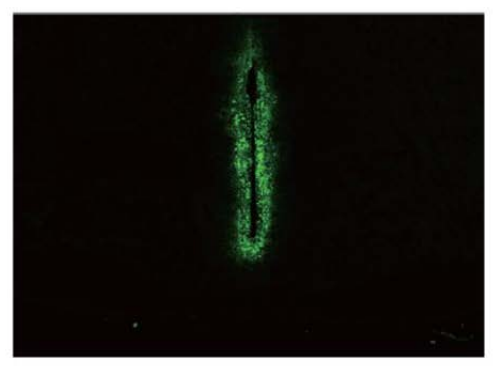

C

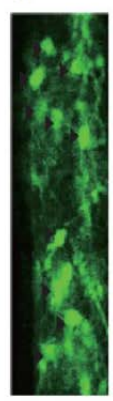

Fig. 3. GFP-positive cells were detected around the third ventricle after intracerebroventricular injection with LV particles. A.B. Images of confocal microscopy using 200-fold magnification are shown. C. Section from A with a higher level of magnification. Arrows represent infected GFP-positive cells.

To do so, we used confocal microscopy to detect GFP fluorescence. We observed that cells around the third ventricle (kiSS1-expressing neurons are mainly distributed in AVPV and ARC which is a thin cell layer around third ventricle) were GFP positive (Fig. 3).

We next examined the efficacy Eap1 suppression in two hypothalamic regions. Rats microinjected with either LV-Eap1-shRNA, LV-eGFP or saline groups were euthanized at the three sexual developmental stages. As expected, RNAi of Eap1 reduced mRNA levels in the LV-Eap1-shRNA injected mice relative to the saline or LV-eGFP injected groups at each of the three developmental stages in the POA/AVPV (Fig. 4 A). We did not observe differences in EAP1 expression amongst the saline and LV-eGFP group as their differences were not significant $(\mathrm{P}>0.05)$. Additionally, the Eap1 protein expression was consistent with mRNA expression. Specifically, we observed reduced Eap1 protein expression upon LV-Eap1-shRNA microinjection relative to saline or LV-eGFP injected groups at all three developmental ages in the AVPV (Fig. 4C). Eap1 protein expression was not perturbed in each control microinjection group. In the ARC, we did not obserbe relative suppression of Eap1 protein or mRNA expression between any of different ages groups (Fig. 4B.D.). These results indicate we successfully suppressed Eap1 in rat POA/AVPV, allowing subsequent examination of Eap1 fuctions in the POA/AVPV.

Eap1 suppression delays vaginal opening and perturbs ovary development.

Eap1 regulates the onset of puberty and the reproductive cycle. We next examined vaginal opening every afternoon from hours 16:00 to 17:00h after the intracerebroventricular injection of LV-Eap1-shRNA. As shown in Fig. 5A, the average time of vaginal opening in the LV-Eap1-shRNA group was significantly delayed compared with that of the saline or LV-eGFP groups. Cinfirming Eap1 POA/AVPV expression as a key component for sexual development. Furthermore, we used H\&E staining to observe the ovarian morphology and function (Fig. 5C). At PND35, CL numbers were lower in the LV-Eap1-shRNA group relative to other developmental stages. However, there appeared to be no difference among groups at PND42 (Fig. 5D). Additionally, we also observe that the ovarian index (ovary weight/body weight) at PND35 was lower in EAP1 suppressed group relative to other groups, and no changes were observed at other developmental stages (Table 3).

Hypothalamic GnRH and KiSS1 expression are didderentially regulated by Eap1 suppression

GnRH, predominantly found in rat POA, integrates critical neuroendocrine signals for hypothalamic regulation of puberty and its expression reflects the activation of the HPG axis. To determine its regulation by Eap1, upon collecting total mRNA from POA/AVPV, we exam- 


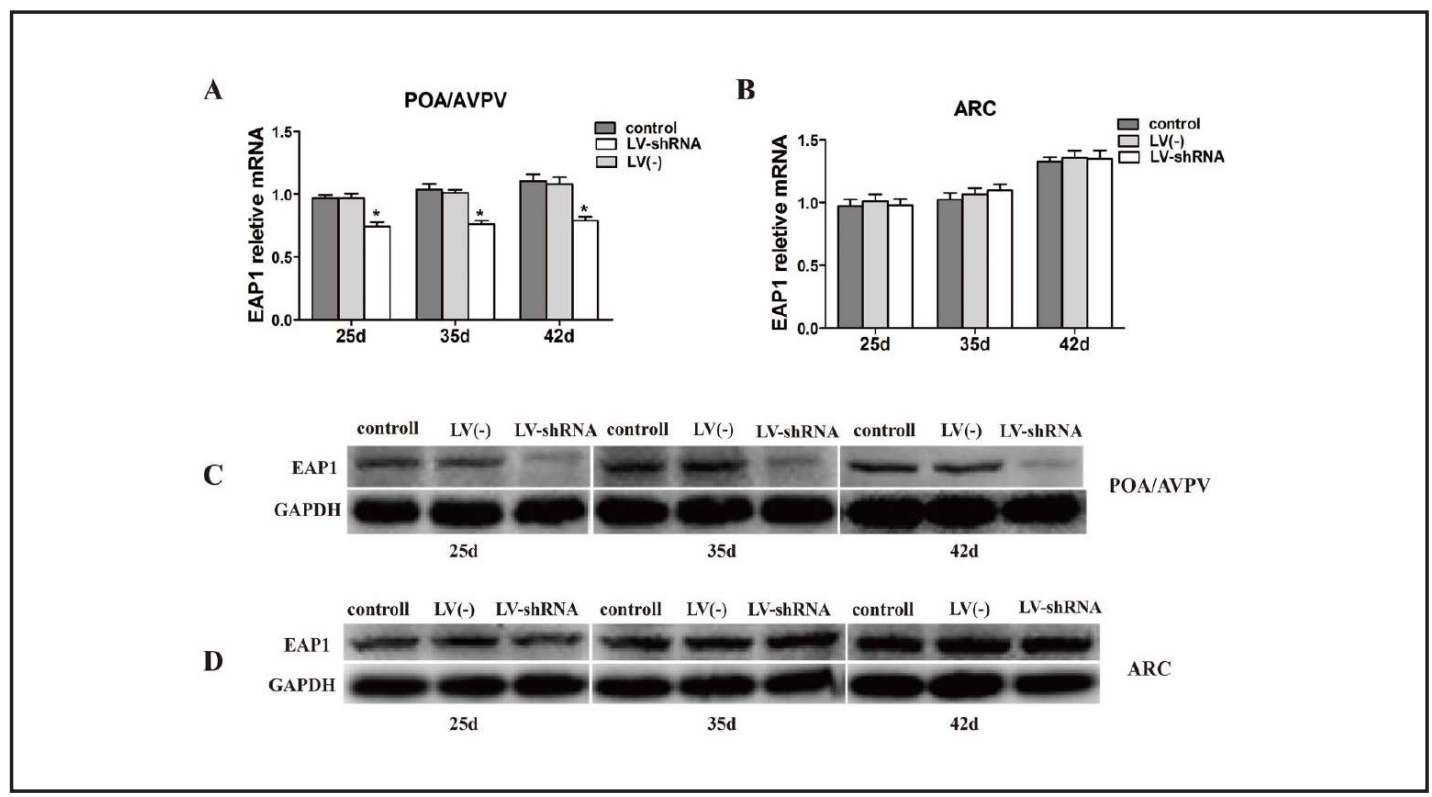

Fig. 4. Hypothalamic expression of Eap1 gene post intracerebroventricular injection. A.B. qPCR analysis of Eap1 mRNA obtained from POA/AVPV and ARC in the three groups from different age stages. Eap1 mRNA in the POA/AVPV is reduced in the LV-EAP1-shRNA group $\left({ }^{*} \mathrm{p}<0.05, \mathrm{n}=8\right)$ relative to the saline and LV-eGFP injected groups in all age stages. However that of the ARC displayed no difference. C.D. Western blot analysis of Eap1. Equal amounts of protein lysates from different age groups were subjected to electrophoresis by SDS-PAGE, transferred to nitrocellulose membrane, and probed with specific antibodies. A representative immunoblot is provided.

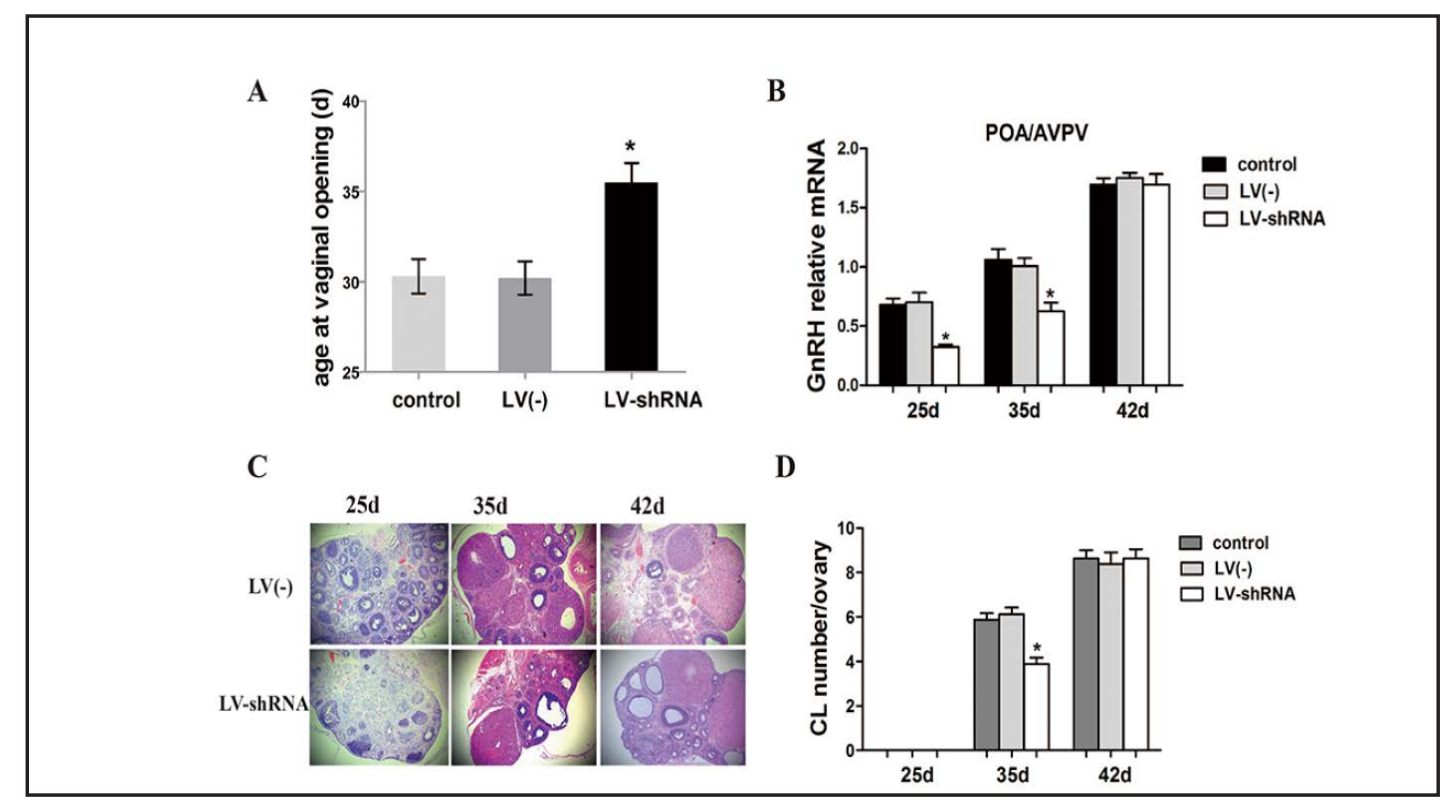

Fig. 5. Sexual development phenotypes associated with Eap1 suppression. A. The onset of vaginal opening is significantly delayed in the LV-Eap1-shRNA group relative to the saline and LV-eGFP groups. B. Hypothalamic GnRH mRNA is reduced in LV-Eap1-shRNA groups in PND25 and PND35, but no differences were observed in the PND42 group ( $\left.{ }^{*} \mathrm{P}<0.05\right)$. C. Pathological assessment of the follicle by H\&E staining. The number of CL in the LV-Eap1-shRNA group was less at PND35 relative to control, whereas no differences were seen at PND42. 


\section{Cellular Physiology Cell Physiol Biochem 2017;43:1402-1412 and Biochemistry \begin{tabular}{l|l|l|l} 
DOI: 10.1159/000481872 & $\begin{array}{l}\text { O 2017 The Author(s). Published by S. Karger AG, Basel } \\
\text { www.karger.com/cpb }\end{array}$
\end{tabular} \\ Li/Li: EAP1 Effect on Kiss1 in Vivo}

Table 3. Ovarian index (ovary weight /body weight $)(\bar{x} \pm s) \times 10^{-4}$. In the early puberty group, the ovarian index of the LV-shRNA group was significantly lower compared to the indices of the saline and LV (-) groups. *, $\mathrm{P}<0.05 ;(\mathrm{n}=8)$

\begin{tabular}{llll}
\hline group & Juvenile & Early puberty & Adult \\
\hline control & $2.35 \pm 0.16$ & $3.24 \pm 0.15$ & $3.63 \pm 0.23$ \\
LV(-) & $2.38 \pm 0.34$ & $3.33 \pm 0.24$ & $3.76 \pm 0.12$ \\
LV-shRNA & $2.17 \pm 0.16$ & $2.68 \pm 0.22^{*}$ & $3.72 \pm 0.13$ \\
\hline
\end{tabular}

A

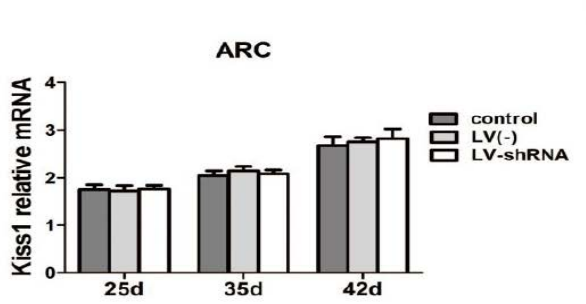

B

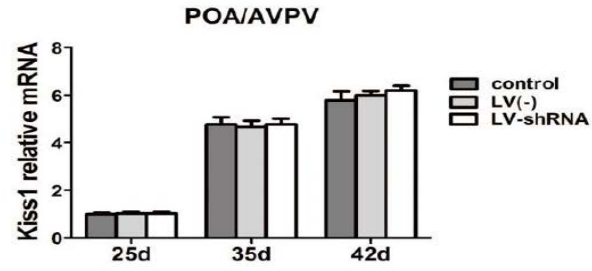

C

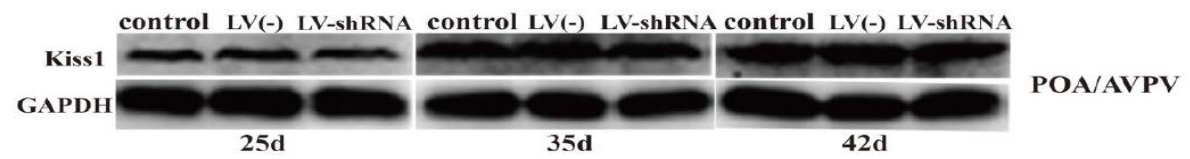

D

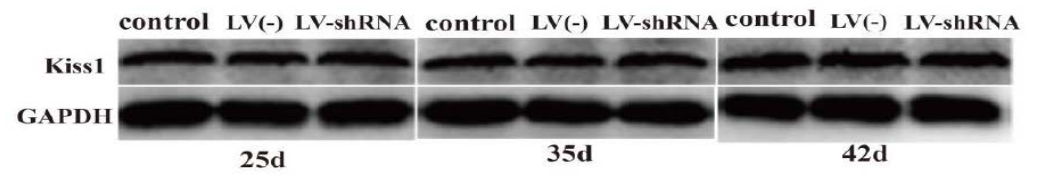

ARC

35

$42 d$

Fig. 6. KiSS1 expression after in vivo Eap1 suppression in the hypothalamus. KiSS1 expression in AVPV and ARC was assessed by qPCR (A, B) and (C, D) western blots normalized to GAPDH signals at each of the three labeled age stages. No significant differences were seen $(\mathrm{P}>0.05)$.

ined relative $G n R H$ transcript levels with qPCR, We noticed that $G n R H$ was reduced in LVEap1-shRNA injected relative to control groups at the juvenile (PND25) and early puberty stages (PND35). However, we obserbed no difference amongst treatment groups at the adult stage (PND42) (Fig. 5B). Our results that associate GnRH regulation to Eap1coincided with phenotypic observations regarding vaginal opening and ovarian index.

Studies have demonstrated that KiSS1 regulates secretion of GnRH. As a key focus, we aimed to determine whether the control of puberty by Eap1 is mediated through KiSS1. In Eap1 suppressed samples, we determined the overall expression of hypothalamic KiSS1 with qPCR and western blots. Despote changes in GnRH, which is a perceived KiSS1 transcripts were not significantly different amongst groups at each developmental stage (Fig. 6A, B, and C). We also did not observe differences in KiSS1 protein expression (Fig. 6E, F, and G). Overall, our results indicate that Eap1 regulated puberty through GnRH without affecting KiSS1.

\section{Discussion}

The loss of Eap1 expression in the medial basal hypothalamus (MBH) of the nonhuman primate hypothalamus abrogates the menstrual cycle [12]. Additionally, Lomniczi et al. [13]. report a single nucleotide polymorphism of the Eap1 gene was associated with amenorrhea or oligomenorrhea in rhesus macaques. These observations demonstrate that Eap1 acts as a key developmental regulator of the female reproduction system in both rodents and nonhuman primates. In this study, we successfully engineered a lentiviral construct and 
further optimized conditions to specifically suppress Eap1 in POA/AVPV via intraventricular microinjection [11, 14]. Eap1 suppression delayed onset of puberty. This observation was accompanied by a decline in ovarian function, as reflected by CL formation, during earlystage puberty. Our findings are consistent with previous studies [4]. Furthermore, we also note that Eap1 suppression in the POA/AVPV led to a decrease in hypothalamic GnRH content, which reflected the observed phenotypic defects. Surprisingly, both mRNA and protein expression of the KiSS1 gene in the AVPV were unchanged by Eap1 suppression, which diffeers from our preceding hypothesis In which Eap1 regulates the secretion of GnRH through KiSS1/GPR54 signaling.

Eap1 is an intronless gene located on chromosome 14q24.3 [15]. Reports agree that it acts upstream of the hypothalamic network that regulates reproductive development and functions. Eap1 contains an N-terminal C4 zinc finger and a C-terminal RING finger domain [16]. The RING finger-containing domain is predicted to participate in proteinprotein interaction and ubiquitination, while the zinc finger domain was hypothesized to be involved in the transcriptional modification of DNA or RNA $[17,18]$. Previous studies have demonstrated that Eap1 transactivates the GnRH promoter but represses the preproenkephalin promoter, inferring that it has a dual transcriptional activity [4]. In 2012, Mueller et al. [19]. discovered that Eap1 was regulated by $t t f 1$, cux1, and yy1. These are upstream components of the Tumor-related gene (TRG) network that also regulate puberty. In Hela cells, Muller et al. [7]. utilized ChIP assays to demonstrate interactions between Eap1 and KiSS1 promoter; this in turn led to repression of KiSS1 expression in Grip-Tite ${ }^{\mathrm{TM}} 293$ MSR cells and GT1-7 neurons. These observarions contradict our findings, and may result from differences in cell lineage or signaling context specific to each cell lines.

In our study, upon in vivo suppression Eap1, we observed no differences in KiSS1 expression, whereas GnRH expression was significantly reduced. Our findings indicate Eap1 signals through the HPG axis by direct regulation of $G n R H$ neurons, which are primarily located in the POA[20]; and this appears to involve pathways other than KiSS1/GPR54. A previous study identifies that Eap1 and GnRH are co-expressed in some neurons and Eap1 directly promotes $G n R H$ expression in GT1-7 cells. This depicts a model in which Eap1 acts on $G n R H$ neurons directly [4]. Nevertheless, our results also demonstrate that even upon Eap1 suppression, GnRH and ovarian function Are normal in adults. By visualizing eGFP-positive cells around the third ventricle, we estimate $60 \%$ of the AVPV/POA neurons were infected by the LV particles [21] and this sufficiently perturbed the onset of puberty. However, effects on puberty were temporal; as the $G n R H$ expression levels eventually recovered. This implies that while Eap1 is important, other factors may also regulate female puberty development, and these genes ultimately amount to a compensatory response. Additionally, despite our findings, we still cannot entirely exclude the role of KiSS1/GPR54 signaling in Eap1-driven puberty. KiSS1 neurons consist of two populations (AVPV and ARC) and KiSS1 neurons may exert distinct biology in each context [22]. As an example, AVPV KiSS1 neurons display a positive feedback to estrogen signals while those of the ARC pertain a negative feedback effect. While we did not observe Eap1 regulation of KiSS1 expression in AVPV, it remains a possibility that it regulates KiSS1 in ARC, in which additional studies are required are necessary to examine this potential regulation.

In temporally controlled fashion, puberty inhibitory genes are predominantly expressed, while these are reduced during the onset of puberty. On the other hand, expression of excitatory genes such as KiSS1, Tac are elevated and initiate sexual maturation [23]. Abreu et al. [24-26]. reported that a loss-of-function mutation of makorin ring finger protein 3 (MKRN3) is a common cause of familial central precocious puberty; this implicates that MKRN3 as a key repressor of puberty control as well as a new pathway of puberty regulation. The discovery of $M K R N 3$ emphasizes the importance of inhibitory signals in the reproductive signaling axis, and that suppression of MKRN3 may also be a required for the initiation of puberty. More recently, Eap1 was shown to be a component of the transcription-repressing complex, also known as interferon regulating factor-2 binding proteins; this inhibits the expression of downstream genes [27]. In conjunction with previous findings in which Eap1

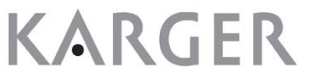




\section{Cellular Physiology Cell Physiol Biochem 2017;43:1402-1412

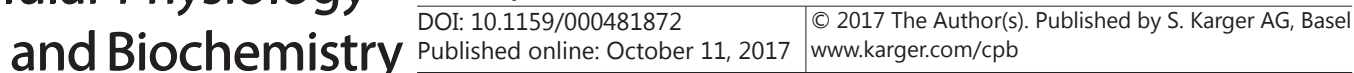 \\ Li/Li: EAP1 Effect on Kiss1 in Vivo}

represses other inhibitory genes. Including preproenkephalin, we speculate Eap1 may broadly function as a transcriptional repressor of several inhibitory factors involved as well. Future studies are required to elucidate the effect of Eap1 suppression of additional inhibitory genes such as MKRN3.

Currently, epidemiological studies indicate that the incidence of precocious puberty in girls has rapidly increased in recent years [28]. Precocious puberty is associated with short adult height, increased breast cancer risk, polycystic ovarian syndrome, reproductive system neoplasms and metabolic syndrome [29]. Improving our understanding of underlying mechanisms that regulate maturation of reproductive systems will contribute to effective strategies in the prevention or treatment of precocious puberty.

\section{Acknowledgements}

This work was financially supported by the National Natural Science Foundation of China (Grant No. 81370686).

\section{Disclosure Statement}

Nothing to delare.

\section{References}

-1 Terasawa E, Fernandez DL: Neurobiological mechanisms of the onset of puberty in primates. Endocr Rev 2001;22:111-151.

-2 Roth CL, Mastronardi C, Lomniczi A, Wright H, Cabrera R, Mungenast AE, Heger S, Jung H, Dubay C, Ojeda SR: Expression of a tumor-related gene network increases in the mammalian hypothalamus at the time of female puberty. Endocrinology 2007;148:5147-5161.

-3 Elks CE, Perry JR, Sulem P, Chasman DI, Franceschini N, He C, Lunetta KL, Visser JA, Byrne EM, Cousminer DL, Gudbjartsson DF, Esko T, Feenstra B, Hottenga JJ, Koller DL, Kutalik Z, Lin P, Mangino M, Marongiu M, McArdle PF, Smith AV, Stolk L, van Wingerden SH, Zhao JH, Albrecht E, Corre T, Ingelsson E, Hayward C, Magnusson PK, Smith EN, Ulivi S, Warrington NM, Zgaga L, Alavere H, Amin N, Aspelund T, Bandinelli S, Barroso I, Berenson GS, Bergmann S, Blackburn H, Boerwinkle E, Buring JE, Busonero F, Campbell H, Chanock SJ, Chen W, Cornelis MC, Couper D, Coviello AD, d'Adamo P, de Faire U, de Geus EJ, Deloukas P, Doring A, Smith GD, Easton DF, Eiriksdottir G, Emilsson V, Eriksson J, Ferrucci L, Folsom AR, Foroud T, Garcia M, Gasparini P, Geller F, Gieger C, Gudnason V, Hall P, Hankinson SE, Ferreli L, Heath AC, Hernandez DG, Hofman A, Hu FB, Illig T, Jarvelin MR, Johnson AD, Karasik D, Khaw KT, Kiel DP, Kilpelainen TO, Kolcic I, Kraft P, Launer LJ, Laven JS, Li S, Liu J, Levy D, Martin NG, McArdle WL, Melbye M, Mooser V, Murray JC, Murray SS, Nalls MA, Navarro P, Nelis M, Ness AR, Northstone K, Oostra BA, Peacock M, Palmer LJ, Palotie A, Pare G, Parker AN, Pedersen NL, Peltonen L, Pennell CE, Pharoah P, Polasek O, Plump AS, Pouta A, Porcu E, Rafnar T, Rice JP, Ring SM, Rivadeneira F, Rudan I, Sala C, Salomaa V, Sanna S, Schlessinger D, Schork NJ, Scuteri A, Segre AV, Shuldiner AR, Soranzo N, Sovio U, Srinivasan SR, Strachan DP, Tammesoo ML, et al.: Thirty new loci for age at menarche identified by a meta-analysis of genome-wide association studies. Nat Genet 2010;42:1077-1085.

4 Heger S, Mastronardi C, Dissen GA, Lomniczi A, Cabrera R, Roth CL, Jung H, Galimi F, Sippell W, Ojeda SR: Enhanced at puberty 1 (eap1) is a new transcriptional regulator of the female neuroendocrine reproductive axis. J Clin Invest 2007;117:2145-2154.

5 Matagne V, Mastronardi C, Shapiro RA, Dorsa DM, Ojeda SR: Hypothalamic expression of eap1 is not directly controlled by ovarian steroids. Endocrinology 2009;150:1870-1878.

-6 Ojeda SR, Lomniczi A, Loche A, Matagne V, Kaidar G, Sandau US, Dissen GA: The transcriptional control of female puberty. Brain Res 2010;1364:164-174.

7 Mueller JK, Dietzel A, Lomniczi A, Loche A, Tefs K, Kiess W, Danne T, Ojeda SR, Heger S: Transcriptional regulation of the human kiss1 gene. Mol Cell Endocrinol 2011;342:8-19.

$>8$ Tng EL: Kisspeptin signalling and its roles in humans. Singapore Med J 2015;56:649-656. 


\section{Cellular Physiology Cell Physiol Biochem 2017;43:1402-1412 \begin{tabular}{l|l|l} 
and Biochemistry Published onlIne: October 11, 2017 & $\begin{array}{l}\text { C } 2017 \text { The Author(s). Published by S. Karger AG, Basel } \\
\text { www.karger.com/cpb }\end{array}$ \\
\hline
\end{tabular}}

9 Xu J, Li P: Expression of eap1 and cux1 in the hypothalamus of female rats and relationship with kiss1 and gnrh. Endocr J 2016;63:681-690.

$>10$ Chen CA, Okayama H: Calcium phosphate-mediated gene transfer: A highly efficient transfection system for stably transforming cells with plasmid DNA. Biotechniques 1988;6:632-638.

11 Zhou SS, Li P: Effects of nell2 on the regulation of gnrh expression and puberty in female rats. Genet Mol Res 2014;13:6672-6682.

12 Dissen GA, Lomniczi A, Heger S, Neff TL, Ojeda SR: Hypothalamic eap1 (enhanced at puberty 1) is required for menstrual cyclicity in nonhuman primates. Endocrinology 2012;153:350-361.

13 Lomniczi A, Garcia-Rudaz C, Ramakrishnan R, Wilmot B, Khouangsathiene S, Ferguson B, Dissen GA, Ojeda SR: A single-nucleotide polymorphism in the eap1 gene is associated with amenorrhea/oligomenorrhea in nonhuman primates. Endocrinology 2012;153:339-349.

14 Ojeda SR, Hill J, Hill DF, Costa ME, Tapia V, Cornea A, Ma YJ: The oct-2 pou domain gene in the neuroendocrine brain: A transcriptional regulator of mammalian puberty. Endocrinology 1999;140:37743789.

15 Rampazzo A, Pivotto F, Occhi G, Tiso N, Bortoluzzi S, Rowen L, Hood L, Nava A, Danieli GA: Characterization of c14orf4, a novel intronless human gene containing a polyglutamine repeat, mapped to the arvd1 critical region. Biochem Biophys Res Commun 2000;278:766-774.

16 Childs KS, Goodbourn S: Identification of novel co-repressor molecules for interferon regulatory factor- 2 . Nucleic Acids Res 2003;31:3016-3026.

17 Saurin AJ, Borden KL, Boddy MN, Freemont PS: Does this have a familiar ring? Trends Biochem Sci 1996;21:208-214.

18 Bohne A, Darras A, D’Cotta H, Baroiller JF, Galiana-Arnoux D, Volff JN: The vertebrate makorin ubiquitin ligase gene family has been shaped by large-scale duplication and retroposition from an ancestral gonadspecific, maternal-effect gene. BMC Genomics 2010;11:721.

19 Mueller JK, Koch I, Lomniczi A, Loche A, Rulfs T, Castellano JM, Kiess W, Ojeda S, Heger S: Transcription of the human eap1 gene is regulated by upstream components of a puberty-controlling tumor suppressor gene network. Mol Cell Endocrinol 2012;351:184-198.

20 Maeda K, Ohkura S, Uenoyama Y, Wakabayashi Y, Oka Y, Tsukamura H, Okamura H: Neurobiological mechanisms underlying gnrh pulse generation by the hypothalamus. Brain Res 2010;1364:103-115.

21 Xu Z, Kaga S, Mochiduki A, Tsubomizu J, Adachi S, Sakai T, Inoue K, Adachi AA: Immunocytochemical localization of kisspeptin neurons in the rat forebrain with special reference to sexual dimorphism and interaction with gnrh neurons. Endocr J 2012;59:161-171.

22 Hu MH, Li XF, McCausland B, Li SY, Gresham R, Kinsey-Jones JS, Gardiner JV, Sam AH, Bloom SR, Poston L, Lightman SL, Murphy KG, O’Byrne KT: Relative importance of the arcuate and anteroventral periventricular kisspeptin neurons in control of puberty and reproductive function in female rats. Endocrinology 2015;156:2619-2631.

-23 Semaan SJ, Kauffman AS: Daily successive changes in reproductive gene expression and neuronal activation in the brains of pubertal female mice. Mol Cell Endocrinol 2015;401:84-97.

24 Abreu AP, Dauber A, Macedo DB, Noel SD, Brito VN, Gill JC, Cukier P, Thompson IR, Navarro VM, Gagliardi PC, Rodrigues T, Kochi C, Longui CA, Beckers D, de Zegher F, Montenegro LR, Mendonca BB, Carroll RS, Hirschhorn JN, Latronico AC, Kaiser UB: Central precocious puberty caused by mutations in the imprinted gene mkrn3. N Engl J Med 2013;368:2467-2475.

25 Abreu AP, Macedo DB, Brito VN, Kaiser UB, Latronico AC: A new pathway in the control of the initiation of puberty: The mkrn3 gene. J Mol Endocrinol 2015;54:R131-139.

-26 Simon D, Ba I, Mekhail N, Ecosse E, Paulsen A, Zenaty D, Houang M, Jesuran Perelroizen M, de Filippo GP, Salerno M, Simonin G, Reynaud R, Carel JC, Leger J, de Roux N: Mutations in the maternally imprinted gene mkrn3 are common in familial central precocious puberty. Eur J Endocrinol 2016;174:1-8.

-27 Teng AC, Kuraitis D, Deeke SA, Ahmadi A, Dugan SG, Cheng BL, Crowson MG, Burgon PG, Suuronen EJ, Chen $\mathrm{HH}$, Stewart AF: Irf2bp2 is a skeletal and cardiac muscle-enriched ischemia-inducible activator of vegfa expression. Faseb j 2010;24:4825-4834.

28 Cisternino M, Arrigo T, Pasquino AM, Tinelli C, Antoniazzi F, Beduschi L, Bindi G, Borrelli P, De Sanctis V, Farello G, Galluzzi F, Gargantini L, Lo Presti D, Sposito M, Tato L: Etiology and age incidence of precocious puberty in girls: A multicentric study. J Pediatr Endocrinol Metab 2000;13:S695-701.

29 Golub MS, Collman GW, Foster PM, Kimmel CA, Rajpert-De Meyts E, Reiter EO, Sharpe RM, Skakkebaek NE, Toppari J: Public health implications of altered puberty timing. Pediatrics 2008;121:S218-230. 